\title{
Peningkatan Partisipasi dan Hasil Belajar Daring Sosiologi Melalui Model Pembelajaran Blended learning Berbasis Moodle
}

\author{
Ridha Ridha \\ SMA Negeri 4 Pariaman \\ Email: rriyuii@gmail.com
}

\begin{abstract}
Abstrak
Penelitian Tindakan Kelas (PTK) ini bertujuan untuk meningkatkan partisipasi belajar dan hasil belajar daring sosiologi dengan menggunakan model pembelajaran Blended Learning berbasis Moodle. di kelas XII IPS 2 SMA Negeri 4 Pariaman. Instrumen pengumpulan data yang digunakan adalah lembar observasi dan hasil ulangan harian peserta didik yang dilaksanakan di setiap siklus. Penelitian ini dilaksanakan dalam dua siklus pada masing-masing siklus terdiri dari perencanaan, tindakan, pengamatan, refleksi. Data yang diperoleh kemudian dianalisis menggunakan rumus statistik deskripstif persentase, dan untuk melihat peningkatan partisipasi siswa dilakukan perbandingan pada setiap siklusnya. Dari hasil penelitian diketahui bahwa partisipasi belajar peserta didik pada siklus I sebesar $82.85 \%$ meningkat pada siklus II menjadi $92.14 \%$. Hasil belajar peserta didik pada siklus I dengan tingkat ketuntasan sebesar $68.57 \%$ meningkat menjadi $88.57 \%$ pada siklus II. Jadi dapat disimpulkan bahwa bahwa penggunaan model pembelajaran Blended Learning berbasis Moodle dapat meningkatkan partisipasi belajar dan hasil belajar Sosiologi di kelas XII IPS 2 SMA Negeri 4 Pariaman.
\end{abstract}

Kata kunci: Partisipasi Belajar, Hasil Belajar, Pembelajaran Online, Blended Learning, Moodle

Abstract

This Classroom Action Research (CAR) aims to increase learning participation and online learning outcomes of sociology by using the Moodle-based Blended Learning learning model. in class XII IPS 2 SMA Negeri 4 Pariaman. The data collection instruments used were observation sheets and students' daily test results carried out in each cycle. This research was carried out in two cycles in each cycle consisting of planning, action, observation, reflection. The data obtained were then analyzed using a descriptive statistical formula of percentages, and to see the increase in student participation, comparisons were made in each cycle. From the results of the study, it was found that the learning participation of students in the first cycle was $82.85 \%$ and increased in the second cycle to $92.14 \%$. The learning outcomes of students in the first cycle with a completeness level of $68.57 \%$ increased to $88.57 \%$ in the second cycle. So it can be concluded that the use of Moodle-based Blended Learning learning model can increase learning participation and Sociology learning outcomes in class XII IPS 2 SMA Negeri 4 Pariaman.

Keywords: Learning Participation, Result Of Learning, Online Learning, Blended Learning, Moodle

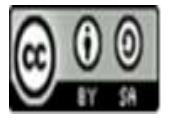




\section{Pendahuluan}

Menyikapi pandemi Covid-19 yang melanda dunia, Kementerian Pendidikan dan Kebudayaan mengeluarkan Surat Edaran (SE) No 3962/MPK/-A/HK/2020 tanggal 17 Maret 2020 perihal pembelajaran secara daring atau pembelajaran jarak jauh. Hal ini sebagai antisipasi terhadap penyebaran virus Corona. Salah satu poin yang ditekankan oleh pemerintah adalah agar pembelajaran konvensional yang dilakukan di sekolah dialihkan dengan pembelajaran jarak jauh dari rumah masing-masing. Keputusan tersebut ditetapkan sebagai upaya mengurangi penyebaran Coronavirus Disease 2019 (COVID 19) yang secara resmi dinyatakan sebagai pandemi oleh World Health Organization (WHO) pada tanggal 11 Maret 2020. Pembelajaran daring (dalam jaringan) atau Pembelajaran Jarak Jauh (PJJ) merupakan sistem pembelajaran tanpa tatap muka secara langsung antara guru dan siswa tetapi dilakukan melalui online yang menggunakan jaringan internet. Sistem pembelajaran jarak jauh ataupun sistem pembelajaran daring terdiri atas dua yaitu sinkron dan asinkron. Pada pembelajaran sinkron, guru dan peserta didik hadir secara bersamaan dalam satu waktu melalui tatap muka daring. Sedangkan pada pembelajaran asinkron peserta didik melakukan kegiatan belajar pada waktu yang berbeda dengan guru ketika memberikan materi. (Hartanto, 2016).

Kementerian Pendidikan dan Kebudayaan mengeluarkan kebijakan kurikulum darurat untuk mempermudah guru dan peserta didik dalam pelaksanaan pembelajaran pada masa pandemi Covid19 ini. Kebijakan kurikulum darurat ini ditetapkan melalui Kepmendikbud Nomor 719/P/2020 tanggal 4 Agustus tentang Pedoman Pelaksanaan Kurikulum pada Satuan Pendidikan dalam Kondisi Khusus. Kurikulum darurat (dalam kondisi khusus) yang disiapkan oleh Kemendikbud merupakan penyederhanaan dari kurikulum nasional. Pelaksanaan kurikulum darurat pada kondisi khusus secara rinci diatur melalui keputusan Kabalitbang Nomor 018/H/KR/2020 tentang Kompetensi Inti dan Kompetensi Dasar pada Kurikulum 2013. Penerapan kurikulum darurat bertujuan untuk memberikan fleksibilitas bagi satuan pendidikan dalam menentukan kurikulum yang sesuai dengan kebutuhan pembelajaran peserta didik. Satuan pendidikan pada kondisi khusus dalam pelaksanaan pembelajaran dapat 1) tetap melaksanakan kurikulum nasional; 2) menerapkan kurikulum darurat; atau 3) menyederhanakan kurikulum secara mandiri. (Menteri Pendidikan dan Kebudayaan Republik Indonesia, 2020).

Perubahan pelaksanaan pembelajaran dari pembelajaran tatap muka menjadi pembelajaran daring dan kebijakan perubahan kurikulum darurat tentunya juga dialami oleh mata pelajaran Sosiologi. Pembelajaran sosiologi di SMA sesungguhnya memiliki peran yang strategis sebab mata pelajaran sosiologi diharapkan mampu meningkatkan kemampuan siswa SMA untuk mengaktualisasikan potensi-potensi diri mereka dalam mengambil dan mengungkapkan status serta peran masing-masing dalam kehidupan sosial dan budaya masyarakat dimana mereka tinggal yang tentu saja mengalami perubahan dari masa ke masa. Dokumen kurikulum 2013 menegaskan bahwa mata pelajaran sosiologi diajarkan untuk mencapai tujuan-tujuan khusus sebagai berikut: 1) meningkatkan penguasaan pengetahuan sosiologi di kalangan peserta didik yang berorientasi pada pemecahan masalah dan pemberdayaan sosial; 2) mengembangkan pengetahuan sosiologi dalam praktek atau praktek pengetahuan sosiologi untuk meningkatkan keterampilan sosial peserta didik dalam memecahkan masalah-masalah sosial; 3) menumbuhkan sikap religious dan etika sosial yang tinggi di kalangan pesrta didik sehingga menimbulkan kepekaan.

Materi-materi yang dipelajari dalam sosiologi sangat kaya informasi atau konsep sebab fokusnya adalah masyarakat dengan budayanya. Untuk itu pembelajaran sosiologi di SMA dimaksudkan untuk mengembangkan kemampuan para peserta didik tentang pemahaman fenomena 


\section{Ridha Ridha \\ Peningkatan Partisipasi dan Hasil Belajar Daring Sosiologi Melalui Model Pembelajaran Blended Learning Berbasis Moodle}

kehidupan masyarakat dengan segala problematikanya yang ada dalam kehidupan sehari-hari mereka, termasuk di dalamnya tentang perubahan sosial dalam masyarakat.

Mengikuti keputusan Kemendikbud dan Peraturan Daerah Sumatera Barat serta peraturan daerah kota Pariaman, terkait pembelajaran jarak jauh atau pembelajaran daring, SMA Negeri 4 Pariaman mulai menghentikan segala aktifitas peserta didik di sekolah dan menggantinya dengan kegiatan belajar di rumah. Dalam pelaksanaan pembelajaran daring, sekolah membuat kebijakan bahwa seluruh aktifitas pembelajaran dapat dilakukan melalui E-Learning SMA Negeri 4 Pariaman dengan aplikasi Moodle. Seluruh guru diwajibkan mengisi konten pembelajaran melalui aplikasi ini, baik materi pelajaran, tugas, kuis, ulangan harian, ujian tengah semester dan ujian akhir semester. Peserta didik belajar, mengirimkan tugas, mengikuti ujian melalui aplikasi Moodle ini. Guru bisa mengkombinasikan dengan aplikasi Zoom dan WhatsApp sebagai sarana interaksi yang lebih luas antara guru dan peserta didik. Misalnya sebagai komunikasi atau pemberitahuan bagi peserta didik untuk bertanya dengan guru tentang hal-hal yang dirasa perlu, juga sebagai media bagi guru untuk menyampaikan peserta didik mana saja yang tugasnya belum lengkap. Jadi Zoom dan WhatsApp digunakan sebagai tempat berdiskusi yang lebih luas. Materi dan konten pelajaran dimasukkan ke dalam aplikasi Moodle.

Proses pembelajaran jarak jauh (PJJ) yang dilakukan dalam kelas daring (Zoom dan WhatsApp) pada umumnya berbentuk penugasan dan diskusi materi. Diskusi dilakukan oleh peserta didik sehingga guru hanya berperan sebagai fasilitator diskusi yang mengawasi dan membimbing aktifitas peserta didik. Tata kelola kelas yang baik dalam proses pembelajaran daring ternyata tidak berbanding lurus dengan partisipasi belajar dan hasil belajar jarak jauh yang dicapai peserta didik.

Partisipasi belajar menuntut keikutsertaan peserta didik untuk bertanggung jawab terhadap pencapaian tujuan belajar. Partisipasi belajar dapat diartikan sebagai keikutsertaan peserta didik dalam suatu kegiatan belajar yang ditunjukkan dengan perilaku fisik dan psikisnya. Selanjutnya Sudjana juga menyebutkan bahwa kegiatan pembelajaran membutuhkan keikutsertaan, atau dengan kata lain, partisipasi peserta didik. Keikutsertaan peserta didik dilaksanakan mulai dari kegiatan pelaksanaan pembelajaran, pelaksanaan sampai dengan evaluasi pembelajaran. Penulis berpendapat bahwa partisipasi belajar bisa dilihat dari partisipasi peserta didik dalam bertanya, partisipasi menjawab pertanyaan, menyimpulkan materi dan partisipasi dalam mengerjakan tugas. (Sudjana, 2006).

Menurut Zainal Arifin, hasil belajar adalah penguasaan yang dicapai oleh siswa dalam mengikuti program pengajaran/belajar mengajar sesuai dengan tujuan yang ditetapkan. (Arifin, 2009). Kemudian Eko Putro Widoyoko (Widoyoko, 2009) mengatakan hasil belajar adalah tingkat penguasaan peserta didik terhadap tujuan-tujuan khusus yang ingin dicapai dalam unit-unit program pengajaran, serta menurut Djemari hasil belajar adalah suatu perubahan yang terjadi pada individu yang belajar, bukan saja perubahan mengenai pengetahuan, tetapi juga pengetahuan untuk membentuk kecakapan, kebiasaan, sikap, pengertian, penguasaan dan penghargaan dalam diri pribadi yang belajar. (Mardapi, 2012). Nana Sudjana mengemukakan hasil belajar adalah kemampuankemampuan yang dimiliki siswa setelah ia mengalami pengalaman belajarnya. Dalam Sistem Pendidikan Nasional, rumusan tujuan pendidikan, baik tujuan kurikuler maupun tujuan instruksional menggunakan klasifikasi hasil belajar dari Benyamin Bloom yang secara garis besar membaginya ke dalam tiga ranah yakni ranah kognitif, ranah afektif dan ranah psikomotoris. (Sudjana, 2006).

Ranah kognitif berkaitan dengan hasil belajar intelaktual yang terdiri dari enam aspek yakni pengetahuan atau ingatan, pemahaman, aplikasi, analisis, sintesis dan evaluasi. Kedua aspek pertama disebut kognitif tingkat rendah dan keempat aspek berikutnya termasuk kognitif tingkat tinggi. Ranah afektif berkenaan dengan sikap yang terdiri dari lima aspek yakni penerimaan, jawaban atau reaksi,

Jurnal Sikola: Jurnal Kajian Pendidikan dan Pembelajaran Vol. 3, No. 2, Th. 2021 
penilaian, organisasi dan internalisasi. Ranah psikomotoris berkenaan dengan hasil belajar keterampilan dan kemampuan bertindak. Ada enam aspek ranah psikomotoris, yakni gerakan refleks, keterampilan gerakan dasar, kemampuan perseptual, keharmonisan atau ketepatan, gerakan keterampilan kompleks, gerakan ekspresif dan interpretatif. Ketiga ranah tersebut menjadi objek penilaian hasil belajar. Di antara ketiga ranah itu, ranah kognitiflah yang paling banyak dinilai oleh para guru di sekolah karena berkaitan dengan kemampuan para siswa dalam menguasai bahan pengajaran.

Selanjutnya Nana Sudjana menyimpulkan bahwa hasil belajar adalah perubahan tingkah laku setelah siswa mengalami pengalaman belajar tertentu. Tingkah laku sebagai hasil belajar dalam pengertian yang luas mencakup bidang kognitif, afektif dan psikomotoris. Selanjutnya Sudjana menyimpulkan pendapat Bloom yang mengatakan bahwa hasil belajar terbagi atas tiga ranah: ranah kognitif, ranah afektif dan ranah psikomotoris. Ranah kognitif berkenaan dengan hasil belajar intelektual, ranah afektif yang berkenaan dengan sikap, ranah psikomotoris yang berkenaan dengan hasil belajar keterampilan dan kemampuan bertindak. (Sudjana, 2006).

Husamah mengemukakan salah satu model pembelajaran yang dapat diterapkan melalui penggunaan media berbasis teknologi adalah model Blended Learning. (Husamah, 2014). Selanjutnya beberapa pemahaman mengenai Blended Learning dari berbagai ahli, Pertama menurut Driscol Blended Learning merupakan pembelajaran yang menggabungkan atau mengkombinasikan berbagai teknologi berbasis web untuk mencapai tujuan pendidikan. (Discoll, 2002); Kedua, Thorne mendefinisikan Blended Learning sebagai campuran dari teknologi e-learning dan multimedia seperti video streaming, virtual class, animasi teks online yang dikombinasikan dengan bentuk-bentuk tradisional di kelas. (Thorne, 2013). Graham menyebutkan Blended Learning secara lebih sederhana sebagai model pembelajaran yang mengkombinasikan antara pembelajaran online dengan pembelajaran face to face atau pembelajaran tatap muka. (Curtis J. Bonk, Charles R. Graham, Jay Cross, 2009). Secara sederhana dapat disebutkan bahwa Blended Learning adalah pembelajaran yang mengkombinasikan antara tatap muka (pembelajaran secara konvensional dengan metode ceramah, penugasan, tanya jawab, demontrasi) dan pembelajaran secara online dengan memanfaatkan berbagai macam media dan teknologi untuk mendukung belajar mandiri dan memberikan pengalaman belajar kepada peserta didik. Dari beberapa pendapat para ahli dapat disimpulkan bahwa model pembelajaran Blended Learning memiliki tiga komponen penting yaitu 1) online learning, 2) pembelajaran tatap muka, 3) belajar mandiri. Melalui Blended Learning dapat menciptakan lingkungan belajar yang positif untuk terjadinya interaksi antara sesama peserta didik, peserta didik dengan pendidiknya tanpa dibatasi ruang dan waktu.

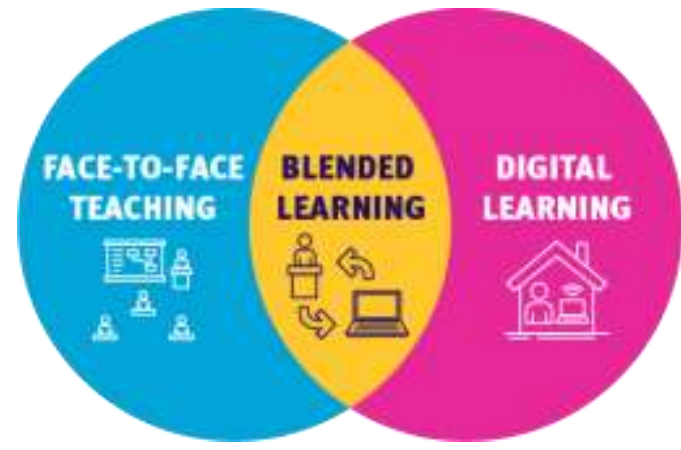

Gambar 1. Ilustrasi Pembelajaran Blended learning (Kaplan Pathway International, 2021)

Jurnal Sikola: Jurnal Kajian Pendidikan dan Pembelajaran Vol. 3, No. 2, Th. 2021 
Aplikasi Modular Objject-Oriented Dynamic Learning Environment atau disingkat Moodle merupakan salah satu platform yang dapat digunakan dalam membuat dan mengembangkan perangkat pembelajaran berbasis elektronik (e-learning). Fungsi dan tujuan dari pengembangan platform ini adalah untuk memudahkan dalam membuat tampilan sistem aplikasi manajemen berbasis web. Selain itu juga berguna untuk model pembelajaran jarak jauh maupun daring yang dapat diakses oleh guru, siswa dan seluruh pemangku kepentingan (stakeholders) dalam proses pembelajaran atau pendidikan. SMA Negeri 4 Pariaman menggunakan Moodle ini dalam proses pembelajaran daring, semua guru memasukkan bahan ajar bisa berupa modul, PPT, gambar, video dan sebagainya yang bisa diakses oleh peserta didik kapan saja. Guru menyampaikan instruksi apa yang akan dibuka dan dipelajari siswa. Guru juga bisa mengunci soal-soal Ulangan Harian atau soal ujian lainnya dan membuka kembali saat dibutuhkan.

Berdasarkan latar belakang di atas, dapat dirumuskan masalah dalam penelitian ini adalah: apakah model pembelajaran Blended Learning berbasis Moodle dapat meningkatkan partisipasi belajar dan hasil belajar sosiologi di kelas XII IPS 3 SMA Negeri 4 Pariaman?. Sedangkan tujuan dari penelitian ini adalah untuk meningkatkan partisipasi belajar dan hasil belajar sosiologi melalui model pembelajaran Blended Learning berbasis Moodle di kelas XII IPS 2 SMA Negeri 4 Pariaman.

\section{Metode Penelitian}

Penelitian ini merupakan Penelitian Tindakan Kelas (PTK) yang dilakukan secara kolaboratif mulai dari tahap perencanaan sampai dengan refleksi. Acuan penelitian ini adalah PTK model Kemmis dan McTanggart yang mencakup perencanaan, tindakan, observasi dan refleksi. (Arikunto, 2008). Pelaksanaan penelitian ini dilaksanakan dalam beberapa siklus, masing-masing siklus untuk 4 kali pertemuan. Adapun kegiatan yang dilakukan pada masing-masing siklus tersebut berpedoman kepada model penelitian tindakan kelas yang dikemukakan Arikunto. Secara garis besar ada 4 tahapan yang dilakukan yaitu: (1) perencanaan, (2) pelaksanaan, (3) pengamatan dan (4) refleksi. Model penelitian tindakan kelas tersebut dapat dilukiskan dalam gambar berikut ini;

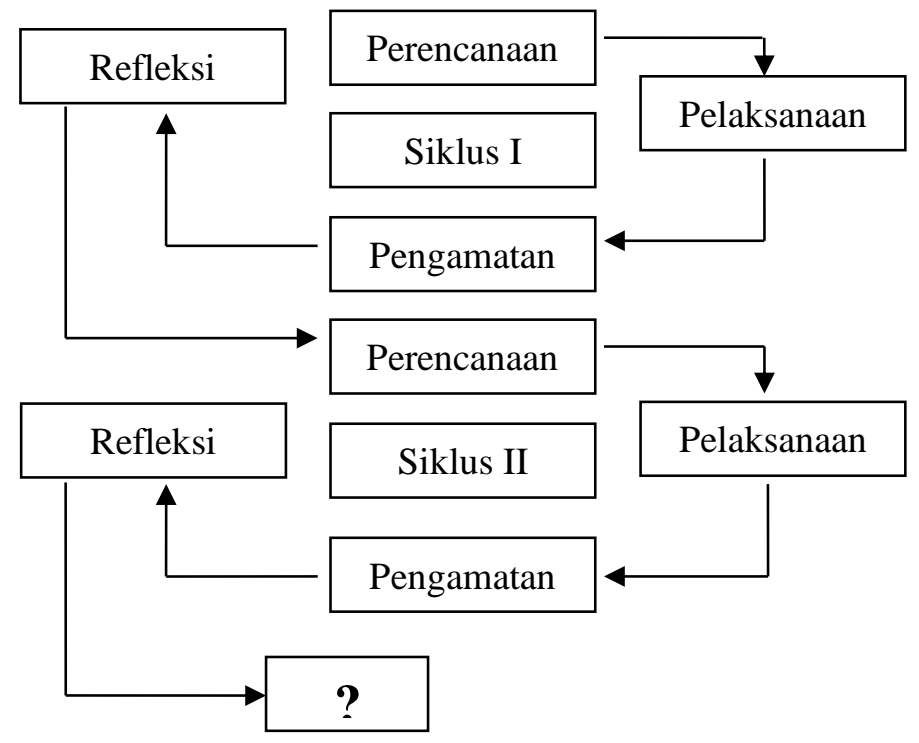

Gambar 2. Model Penelitian Tindakan Kelas (Arikunto, 2008)

Jurnal Sikola: Jurnal Kajian Pendidikan dan Pembelajaran Vol. 3, No. 2, Th. 2021 
Penelitian ini dilaksanakan di SMA Negeri 4 Pariaman kelas XII IPS 2 dengan jumlah siswa 35 orang. Penelitian dilaksanakan dalam dus siklus. Siklus 1 dalam empat kali pertemuan dan siklus 2 dalam tiga kali pertemuan. Sehingga total waktu yang dipakai adalah tujuh kali pertemuan yang masing-masing berdurasi dua jam pelajaran, pada masa pandemi ini satu jam pelajaran berdurasi 30 menit. Siklus 1 dilaksanakan 11. 18, 25 Januari dan 1 Februari 2021. Siklus 2 dilaksanakan tanggal 8, 15 dan 22 Februari 2021.

Karena saat diadakannya Penelitian Tindakan Kelas ini pada saat pandemi Covid-19, maka pelaksanaannya dilakukan secara daring menggunakan pembelajaran sinkron dan asinkron. Guru sosiologi bertindak sebagai tenaga peneliti dan dibantu oleh seorang kolaborator. Materi pokok pembelajaran adalah ketimpangan sosial. Masing-masing siklus terdiri empat tahap yaitu perencanaan, pelaksanaan, observasi dan refleksi. Prosedur penelitian pada setiap siklus dilaksanakan sebagai berikut:

\section{Instrumen dan Teknik Pengumpulan Data}

Instrumen yang digunakan dalam penelitian ini adalah lembar observasi untuk mengukur partisipasi belajar peserta didik dan hasil ulangan harian untuk mengukur hasil belajar. Indikator keberhasilan PTK ditetapkan sebagai berikut:

1. Partisipasi belajar peserta didik berada pada angka minimal $\geq 75 \%$ per aspek dan $85 \%$ dari keseluruhan aspek partisipasi belajar. Penentuan persentase selama proses pembelajaran diukur dari hasil observasi yang dilakukan oleh observer dan dinyatakan dalam bentuk persentase.

2. Hasil belajar peserta didik mencapai Kriteria Ketuntasan Minimal (KKM) 80 dengan jumlah peserta didik yang tuntas sebanyak $85 \%$ yaitu sebanyak 30 orang.

\section{Teknik Analisis Data}

Data yang didapat dalam Penelitian Tindakan Kelas ini ada dua macam yaitu data partisipasi belajar dan data hasil belajar. Data partisipasi belajar didapatkan dari lembar observasi dan data hasil belajar didapatkan dari hasil ulangan harian peserta didik. Data-data ini diperoleh pada saat pembelajaran sosiologi tentang materi Ketimpangan Sosia

\section{Teknik Analisis Lembar Observasi}

Penelitian Tindakan Kelas ini akan melihat partisipasi belajar menyangkut partisipasi bertanya, partisipasi menjawab pertanyaan, partisipasi menyimpulkan materi dan partisipasi mengerjakan tugas. Semua indikator tersebut diamati melalui aktifitas diskusi di WhatsApp grup, aktifitas saat presentasi tatap muka dan melalui Zoom, juga pengumpulan tugas.

Nana Sudjana (2005) mengatakan bahwa hasil observasi dengan skala nilai dapat dihitung dengan cara:

1) Menjumlahkan seluruh skor yang diperoleh peserta didik masing-masing indikator.

2) Menghitung rata-rata untuk pencapaian per aspek yang diamati.

3) Mengkonversikan hasil rata-rata ke dalam standar $100 \%$.

4) Menghitung rata-rata keseluruhan aspek.

5) Mengklasifikasikan dalam kategori tertentu.

\section{Teknik Analisis Hasil Belajar}

Data hasil belajar didapatkan dari ulangan harian yang dilaksanakan pada siklus I dan siklus II yang dilakukan melalui e-learning SMA Negeri 4 Pariaman yaitu Moodle sehingga didapatkan dua hasil belajar. Hasil belajar akan dirata-rata secara klasikal untuk masing-masing siklus. Pencapaian 
KKM dinyatakan dengan persentase agar dapat dinilai perkembangan hasil belajar peserta didik dari masing-masing siklus.

\section{Hasil dan Pembahasan}

\section{Pelaksanaan Penelitian}

Model pembelajaran Blended Learning berbasis Moodle ini penulis gunakan dalam pembelajaran daring sosiologi pada kompetensi "ketimpangan sosial". Peserta didik diharapkan mampu memahami hakekat dari ketimpangan sosial, faktor penyebab ketimpangan sosial, aspek ketimpangan sosial, dampak ketimpangan sosial dan bentuk ketimpangan sosial dalam kehidupan masyarakat. Pada tahap awal guru melakukan diskusi dengan peserta didik melalui WhatsApp Group dilanjutkan melalui Zoom tentang bagaimana membuat rumusan masalah, materi yang berkaitan dengan ini telah ada dalam aplikasi e learning SMAN 4 Pariaman yaitu aplikasi Moodle. Kemudian peserta didik melakukan pengamatan dari berbagai sumber data dan menalar serta pemecahan masalah melalui diskusi. Guru melakukan bimbingan secara daring dan tatap muka terbatas.

\section{Siklus I}

\section{Perencanaan}

Pada tahap perencanaan, peneliti bersama guru kolaborator berdiskusi tentang permasalahan pembelajaran yang terjadi di kelas. Penulis dan kolaborator berpendapat bahwa selama masa pandemi ini terlihat partisipasi belajar peserta didik dirasa kurang dalam proses pembelajaran. Guru kolaborator mengusulkan adanya tindakan untuk memperbaiki partisipasi belajar dan hasil belajar peserta didik.

Materi pokok dalam penelitian tindakan kelas ini adalah ketimpangan sosial dengan Kompetensi Dasar 3.3. Memahami faktor penyebab ketimpangan sosial dan pertautannya dengan perubahan sosial di tengah-tengah globalisasi. Sedangkan Kompetensi Dasar 4.3. Mengolah hasil kajian dan pengamatan tentang ketimpangan sosial sebagai akibat dari perubahan sosial di tengah-tengah globalisasi. Selanjutnya peneliti menyusun rencana pembelajaran dengan sub materi hakekat ketimpangan sosial, hal-hal yang melatarbelakangi terjadinya ketimpangan sosial dan aspek-aspek ketimpangan sosial. Guru menyiapkan bahan ajar berupa materi dalam bentuk modul dan PPT, tugas dan soal untuk tes ke dalam e-learning yang berbentuk Moodle. Guru bersama dengan kolaborator yang selanjutnya juga bertindak sebagai observer juga menyusun lembar observasi.

\section{Pelaksanaan}

Pelaksanaan siklus I sebanyak 4 kali yaitu tiga kali pertemuan daring dengan guru berada di SMAN 4 Pariaman sedangkan peserta didik di rumah masing-masing, satu kali pertemuan tatap muka terbatas di SMAN 4 Pariaman. Pada masa pandemi ini sekolah mengizinkan kepada guru yang akan melaksanakan pertemuan terbatas dengan siswa asalkan mematuhi syarat-syarat dan protokoler covid-19. Sekolah mengizinkan jika ada guru yang akan melakukan bimbingan terbatas semisal pembinaan untuk kegiatan persiapan olimpide atau pun bimbingan karya tulis ilmiah (KTI), tak terkecuali pelaksanaan PBM. Adapun pelaksanaan pembelajaran yang dilakukan pada siklus I adalah sebagai berikut:

1) Pertemuan Pertama (11 Januari 2021)

Pembelajaran dilaksanakan secara asinkron melalui aplikasi WhatsApp Group dan kelompok kecil. Guru memberikan instruksi pada peserta didik agar mempelajari materi yang telah ada dalam aplikasi Moodle yaitu tentang ketimpangan sosial. Guru juga menjelaskan tentang tahapan 
pembelajaran yang akan dilakukan siswa. Selanjutnya guru membagi siswa ke dalam empat kelompok, tiga kelompok masing-masingnya berjumlah sembilan orang dan satu kelompok berjumlah delapan orang. Peserta didik berdiskusi melalui WhatsApp Group masing-masing untuk menyusun resume sesuai topik yang telah diberikan seperti yang terdapat pada tabel 1 . Selain mempelajari materi pelajaran yang diberikan guru melalui aplikasi Moodle peserta didik dapat menggunakan media buku pelajaran, internet, koran atau sumber belajar lainnya untuk menunjang diskusi kelompok.

Tabel 1. Pembagian Topik Bahasan pada Siklus I

\begin{tabular}{cl}
\hline Kelompok & \multicolumn{1}{c}{ Topik } \\
\hline 1 & Hakekat ketimpangan sosial \\
\hline 2 & Stratifikasi dalam sistem dunia \\
\hline 3 & Faktor penyebab ketimpangan sosial \\
\hline 4 & Aspek-aspek ketimpangan sosial \\
\hline & Sumber: Data Primer (2021)
\end{tabular}

2) Pertemuan Kedua (18 Januari 2021)

Pada pertemuan kedua, pembelajaran dilaksanakan dengan berdiskusi secara daring. Guru mengawasi dan mengarahkan diskusi melalui WhatsApp Group yang digunakan sebagai ruang kelas daring. Pada pertemuan kedua ini, kelompok satu dan kelompok dua mempresentasikan hasil diskusinya dan kelompok lain menanggapi. Guru memberikan tugas individu kepada peserta didik berupa soal-soal latihan yang ada dalam Moodle.

3) Pertemuan Ketiga (25 Jahuari 2021)

Pada pertemuan ketiga, pembelajaran dilanjutkan dengan diskusi bagi kelompok 3 dan kelompok 4 untuk mempresentasikan hasil kerja kelompok mereka melalui WhatsApp Group. Kelompok lain menanggapi apa-apa yang dipresentasikan kelompok 3 dan 4 . Guru memberikan tugas mandiri kepada peserta didik melalui Moodle.

4) Pertemuan Keempat (1 Februari 2021)

Pada pertemuan keempat ini, dilakukan secara tatap muka terbatas. Guru menginstruksikan $50 \%$ dari masing-masing kelompok untuk hadir pada jam $09.00 \mathrm{Wib}$ sampai dengan $10.00 \mathrm{Wib}$ dan $50 \%$ lainnya pada pukul $10.30 \mathrm{Wib}$ sampai dengan $11.30 \mathrm{Wib}$. Pada pertemuan kali ini guru bersamasama dengan peserta didik mengulang materi yang telah didiskusikan. Guru dan peserta didik menyimpulkan pelajaran. Di akhir pelajaran, guru menginstruksikan peserta didik untuk mengerjakan Ulangan Harian melalui Moodle.

\section{Observasi}

Saat pelaksanaan observasi, peneliti dan guru kolaborator berada di tengah-tengah pembelajaran daring maupun tatap muka untuk mengamati kegiatan guru dan peserta didik. Proses pengamatan ditekankan pada tingkat partisipasi peserta didik pada tiap pertemuan.

\section{Refleksi}

Tahap refleksi dilaksanakan setelah pelaksanaan tindakan dan observasi. Tahap ini berfungsi sebagai evaluasi pelaksanaan dan hasil suklus I, diharapkan dapat dilakukan perbaikan dalam pelaksanaan siklus II. 


\section{Siklus II}

\section{Perencanaan}

Diskusi dengan kolaborator membahas tentang penyebab kurangnya partisipasi siswa dalam belajar karena kurangnya kelengkapan belajar siswa dan belum maksimalnya siswa dalam belajar. Untuk itu diambil keputusan untuk meningkatkan partisipasi dan hasil belajar dengan memberikan pengertian bahwa partipasi siswa dalam belajar (partisipasi bertanya, partisipasi menjawab pertanyaan, partisipasi menyimpulkan materi dan partisipasi mengerjakan tugas) akan memiliki nilai tambah dan akan mempengaruhi nilai rapor.

Peneliti menyusun rencana pembelajaran dengan materi ketimpangan sosial sehubungan dengan: faktor yang mempengaruhi ketimpangan sosial, dampak ketimpangan sosial, bentuk ketimpangan sosial dan usaha mengatasi ketimpangan sosial. Guru menyiapkan bahan ajar berupa materi, soal latihan dan soal ulangan harian dalam Moodle. Peneliti menginformasikan kepada peserta didik bahwa materi selanjutnya merupakan lanjutan dari materi pada siklus I.

\section{Pelaksanaan}

Siklus II dilaksanakan dalam tiga pertemuan. Peserta didik diberikan topik sesuai dengan tabel 2 pada siklus II, intruksi mengenai tahapan dan prosedur disampaikan melalui WhatsApp Group.

\section{Tabel 2. Pembagian Topik Bahasan pada siklus II}

\begin{tabular}{cl} 
Kelompok & \multicolumn{1}{c}{ Topik } \\
\hline 1 & Faktor yang mempengaruhi ketimpangan sosial \\
\hline 2 & Dampak ketimpangan sosial \\
\hline 3 & Bentuk-bentuk ketimpangan sosial \\
\hline 4 & Usaha mengatasi ketimpangan sosial \\
\hline
\end{tabular}

Sumber: Data Primer (2021)

1) Pertemuan Pertama (8 Februari 2021)

Pertemuan pertama dilakukan secara asinkron melalui WhatsApp Group, Kelompok 1 dan Kelompok 2 menyampaikan resume sementara kelompok lainnya menanggapi, guru memberikan tugas individu yang bisa dilihat dalam aplikasi Moodle.

2) Pertemuan Kedua (15 Februari 2021)

Pertemuan kedua juga dilakukan secara asinkron, kelompok 3 dan kelompok 4 menyampaikan hasil diskusinya dan kelompok lain menanggapi, guru memberikan tugas mandiri melalui Moodle.

3) Pertemuan Ketiga (22 Februari 2021)

Pertemuan ketiga dilakukan secara sinkron melalui zoom. Masing-masing perwakilan dari empat kelompok menyampaikan simpulan dari hasil diskusi dan masukan dari kelompok lain pada saat diskusi pertemuan pertama dan kedua. Selanjutnya pada akhir siklus II guru memberikan ulangan harian.

\section{Observasi}

Pada tahap ini, guru kolaborator mengamati kegiatan guru dan peserta didik selama kegiatan penelitian tindakan kelas ini berlangsung. Instrumen yang digunakan adalah lembar observasi untuk melihat keterlaksanaan proses pembelajaran pada siklus I dan siklus II. 


\section{Refleksi}

Refleksi dilakukan setelah tindakan untuk melihat keberhasilan dari hasil observasi dan hasil ulangan harian peserta didik. Tahap ini berfungsi sebagai evaluasi bagi guru mengenai pelaksanaan dari hasil siklus II sehingga dapat ditarik kesimpulan apakah siklus akan dilanjutkan atau dicukupkan sampai siklus II saja. Guru berdiskusi dengan kolaborator mengenai indikator keberhasilan, hasil observasi terhadap partisipasi serta hasil belajar peserta didik. Dari hasil diskusi diambil kesimpulan bahwa indikator minimal dari indikator keberhasilan telah dicapai serta mempertimbangkan keterbatasan waktu dan biaya maka penelitian ini dilaksanakan dalam dua siklus.

Dari hasil observasi yang dilakukan oleh peneliti dan kolaborator didapatkan hasil rekapitulasi perbandingan persentase partisipasi belajar siswa dalam siklus I dan siklus II sebagai berikut:

Tabel 3. Data Perbandingan Rekapitulasi Partisipasi Belajar Siklus I dan Siklus II

\begin{tabular}{clccc}
\hline $\begin{array}{l}\text { N } \\
\mathbf{0}\end{array}$ & Aspek Partisipasi Belajar & $\begin{array}{c}\text { Siklus I } \\
\mathbf{( \% )}\end{array}$ & $\begin{array}{c}\text { Siklus II } \\
\mathbf{( \% )}\end{array}$ & $\begin{array}{c}\text { Peningkatan dari } \\
\text { Siklus I dan Siklus II } \\
\text { (\%) }\end{array}$ \\
\hline 1 & Partisipasi bertanya & 82,85 & 85,71 & 2,86 \\
2 & Partisipasi menjawab pertanyaan & 80,00 & 91,42 & 11,42 \\
3 & Partisipasi menyimpulkan materi & 77,14 & 91,42 & 14,28 \\
4 & Partisipasi mengerjakan tugas & 91,42 & 100,00 & 8,58 \\
\hline \multicolumn{2}{c}{ Rata-rata } & 82,85 & 92,14 & 9,29 \\
\hline
\end{tabular}

Sumber: Data Primer (2021)

Dari tabel di atas dapat dilihat bahwa pada siklus I rata-rata partisipasi belajar peserta didik sebesar 82,85 \% sementara pada siklus II sebesar 92,14\% terjadi peningkatan sebanyak 9,29\%. Dari tabel 3 di atas juga dapat dilihat bahwa peningkatan partisipasi tertinggi pada aspek menyimpulkan materi dari siklus I sebesar $77,14 \%$ menjadi $91,42 \%$ pada siklus II, terjadi peningkatan sebesar $14,28 \%$. Peningkatan tersebut terjadi karena guru sebagai peneliti pada siklus II lebih menekankan pada setiap peserta didik untuk berperan aktif dalam membuat kesimpulan atau materi yang akan disampaikan pada saat presentasi. Guru juga menyampaikan bagi yang tidak berpartisipasi dalam menyimpulkan materi maka nilainya akan kosong.

Peningkatan terendah terdapat pada aspek partisipasi bertanya yaitu sebesar $82,85 \%$ pada siklus I dan sebesar 85,71 pada siklus II yang menunjukkan terjadinya peningkatan sebesar $2,86 \%$. Partisipasi bertanya pada siklus II juga menunjukkan persentase yang paling rendah dibandingkan dengan partisipasi menjawab pertanyaan, partisipasi menyimpulkan materi dan partisipasi mengerjakan tugas yang sudah menunjukkan persentase di atas $90 \%$. Hal ini disebabkan peserta didik ada yang tidak mengajukan pertanyaan pada saat pembelajaran karena mereka menganggap telah ada teman dalam kelompoknya yang mewakili untuk bertanya.

Dari tabel 3 juga bisa dilihat bahwa pembelajaran pada siklus II lebih baik dibandingkan dengan siklus I. hal ini terjadi karena perbaikan pembelajaran pada siklus II dilakukan berdasarkan hasil refleksi dari siklus I.

Dari data dan uraian di atas dapat dijelaskan bahwa indikator keberhasilan PTK yang peneliti tetapkan dalam hal partisipasi belajar telah tercapai yaitu partisipasi belajar peserta didik berada pada angka minimal $\geq 75 \%$ per aspek dan $\geq 85 \%$ pada keseluruhan asepek partisipasi belajar. Masingmasing aspek pada siklus II sudah berada pada angka di atas $75 \%$ dengan rincian aspek partisipasi bertanya $85,71 \%$, aspek partisipasi menjawab pertanyaan $91,42 \%$, aspek partisipasi menyimpilkan 


\section{Ridha Ridha \\ Peningkatan Partisipasi dan Hasil Belajar Daring Sosiologi Melalui Model Pembelajaran Blended Learning Berbasis Moodle}

materi 91,42\% dan aspek mengumpulkan tugas sebesar 100\% yang berarti seluruh peserta didik sudah mengumpulkan tugas yang diberikan guru. Indikator $\geq 85 \%$ untuk keseluruhan aspek juga sudah tercapai dengan rata-rata keseluruhan aspek 92,14\%.

Sejalan dengan peningkatan partisipasi belajar, penelitian ini juga melihat peningkatan hasil belajar dari peserta didik.

Tabel 4. Perbedaan Hasil Belajar antara Siklus I dan Siklus II

\begin{tabular}{lll}
\hline \multicolumn{1}{c}{ Kriteria } & Siklus I & Siklus II \\
\hline Jumlah siswa yang tuntas & 25 & 31 \\
\hline Persentase tuntas & 68,57 & 88,57 \\
\hline Jumlah siswa yang tidak tuntas & 10 & 4 \\
\hline Persentase tidak tuntas & 28,57 & 11,42 \\
\hline Nilai tertinggi & 85 & 100 \\
\hline Nilai terendah & 55 & 65 \\
\hline Rata-rata & 76,42 & 87,86 \\
\hline
\end{tabular}

Sumber: Data Primer (2021)

Dari tabel 4 dapat dilihat perbedaan hasil belajar antara siklus I dan siklus II. Dari tabel tersebut terlihat telah terjadi perbaikan hasil belajar antara siklus I dan siklus II. Pada siklus I jumlah siswa yang tuntas sebanyak 25 orang (68.57\%) meningkat menjadi 31 orang (88.57\%) pada siklus II dengan kata lain telah terjadi penurunan jumlah siswa yang tidak tuntas pada siklus I sebanyak 10 orang (28.57\%) menjadi sebanyak 4 orang (11.42\%) pada siklus II. Hal ini disebabkan pada siklus II peserta didik lebih ditekankan untuk meningkatkan partisipasi belajarnya, terutama dalam hal partisipasi menyimpulkan materi yang pada siklus I sangat rendah. Karena dengan aktif berpartisipasi dalam kegiatan pembelajaran maka peserta didik akan lebih memahami materi yang diberikan. Ketuntasan klasikal $\geq 75 \%$ pada siklus I juga belum tercapai karena persentase tuntas baru mencapai $68.57 \%$. Pada siklus II sudah memenuhi kriteria ketuntasan klasikal karena persentase tuntas pada siklus II sudah mencapai $88.57 \%$

Peningkatan juga terjadi pada kriteria nilai tertinggi dan nilai terendah. Pada siklus I nilai tertinggi 85 sedangkan pada siklus II sudah mencapai nilai maksimal yaitu 100. Nilai terendah pada siklus I sebesar 55, pada siklus II sebesar 65. Pergeseran peningkatan nilai ini menunjukkan bahwa bukan hanya tingkat ketuntasan yang menjadi indikasi perbaikan hasil belajar peserta didik namun dari segi rentang nilai juga menunjukkan adanya perbaikan atau peningkatan.

Perbaikan hasil belajar yang diperoleh merupakan implikasi positif dari pelaksanaan tindakan pada proses pembelajaran di setiap siklus. Penerapan pembelajaran daring dengan model Blended Learning membuat peserta didik lebih mudah memahami materi dan berpartisipasi dalam belajar dibandingkan dengan hanya pembelajaran daring murni, pemakaian Moodle juga mendukung hal ini. Pembelajaran Blended Learning berbasis Moodle dapat memberikan manfaat dalam pelaksanaan pembelajaran sekaligus meningkatkan kualitas pendidikan, karena memberikan kesempatan kepada siswa untuk bekerja secara pribadi dengan guru, guru akan memiliki lebih banyak cara untuk mendukung siswanya. Selain itu guru dapat lebih mudah dan cepat melacak data dan kemajuan siswa dengan memanfaatkan platform online.

Hasil penelitian ini memperlihatkan bahwa pelaksanaan pembelajaran Blended Learning berbasis Moodle pada mata pelajaran Sosiologi memberikan manfaat dapat: (1) Membantu guru untuk berkembang lebih baik didalam proses belajar, sesuai dengan gaya belajar dan preferensi dalam 


\section{Ridha Ridha \\ Peningkatan Partisipasi dan Hasil Belajar Daring Sosiologi Melalui Model Pembelajaran Blended Learning Berbasis Moodle}

belajar; (2) Menyediakan peluang yang praktis realistis bagi guru untuk melaksanakan pembelajaran secara mandiri, bermanfaat, dan terus berkembang; (3) Peningkatan penjadwalan fleksibilitas bagi guru, dengan menggabungkan aspek tatap muka dan instruksi online. Kelas tatap muka dapat digunakan untuk melibatkan para siswa dalam pengalaman interaktif. Sedangkan kelas online memberikan para siswa dengan konten multimedia yang kaya akan pengetahuan pada setiap saat, dan di mana saja selama pendidik memiliki akses internet. Namun juga terdapat beberapa kekurangan yaitu: (1) Media yang dibutuhkan sangat beragam, sehingga sulit diterapkan apabila sarana dan prasarana tidak mendukung; (2) Tidak meratanya fasilitas yang dimiliki pelajar, seperti komputer dan akses internet. Sehingga dapat menyulitkan peserta dalam mengikuti pembelajaran mandiri via online; (3) Kurangnya pengetahuan masyarakat terhadap penggunaan teknologi. (Tri Mughni Indriani, Toto Fathoni, 2018).

Pendidikan di Indonesia saat ini dituntut untuk mempersiapkan peserta didik yang cerdas, kreatif serta mandiri. Pendidikan yang bermutu harus mencakup dua orientasi yakni orientasi akademis yang menitik beratkan pada peserta didik, dan orientasi ketrampilan hidup untuk memberi bekal kepada peserta didik agar dapat menghadapi kehidupan nyata atau sesungguhnya. Pengintegrasian teknologi informasi telah menjadi bagian dari pembelajaran sehingga menuntut sekolah agar dapat memfasilitasinya. Namun, peran guru dalam pembelajaran tatap muka (face to face) tidak dapat digantikan dengan teknologi apapun. Keberhasilan dalam pendidikan sangat ditentukan oleh bagaimana pelaksanaan proses pembelajaran, pelaksanaan pembelajaraan tidak akan lepas dari keterpaduan antara guru dan siswa. (Mardian \& Sylvia, 2020). Diantara keduanya terdapat hubungan atau komunikasi interaksi. Pada saat proses kegiatan pembelajaran berlangsung terdapat komponenkomponen ataupun faktor-faktor yakni: alat bantu mengajar penilaian pembelajaran, situasi pembelajaran dan tujuan dalam pembelajaran. (Oemar Hamalik, 2001). Materi pelajaran yang dimasukkan ke dalam Moodle bisa diakses kapan saja dan dimana saja oleh peserta didik. Guru bisa memasukkan materi dalam bentuk word, PPT, gambar, video pembelajaran dan lainnya. Hal ini senada dengan penelitian yang dilakukan oleh Wibiatmoko Herbimo bahwa penerapan aplikasi Moodle sebagai salah satu model pembelajaran jarak jauh di masa pandemi dapat meningkatkan hasil belajar siswa di kelas X di SMK Negeri 4 Yogyakarta. (Herbimo, 2020).

\section{Kesimpulan}

Berdasarkan hasil penelitian yang dilakukan di kelas XII IPS 2 SMA Negeri 4 Pariaman dapat disimpulkan bahwa rata-rata partisipasi belajar daring peserta didik pada siklus I sebesar $82,85 \%$ sedangkan pada siklus II meningkat menjadi 92,4\%. Rata-rata hasil belajar pada siklus I sebesar 76,42 sedangkan pada siklus II meningkat menjadi 87,81 . Tingkat ketuntasan belajar peserta didik pada siklus I sebesar 68,57\% sedangkan pada siklus II meningkat menjadi 88,57\%. Maka dapat disimpulkan bahwa penggunaan model pembelajaran Blended learning berbasis Moodle dapat meningkatkan partisipasi belajar dan hasil belajar di kelas XII IPS 2 SMA Negeri 4 Pariaman.

Sehubungan dengan berbagai proses yang telah dilalui selama penelitian tindakan kelas ini berlangsung maka peneliti menyarankan beberapa hal berikut:

1) Kegiatan pembelajaran dengan menggunakan model Blended learning berbasis Moodle dapat menjadi salah satu alternatif bagi guru untuk meningkatkan partisipasi dan hasil belajar peserta didik.

2) Sangat diperlukan penguasaan teknologi yang baik untuk guru dan peserta didik, terutama dalam mendukung pelaksanaan pembelajaran daring. 
3) Masyarakat terutama orang tua peserta didik sebaiknya memberikan dukungan terhadap pembelajaran daring agar peserta didik bisa terlibat aktif dalam pembelajaran.

\section{Daftar Pustaka}

Arifin, Z. (2009). Evaluasi Pembelajaran. Bandung: PT. Remaja Rosdakarya.

Arikunto, S. \& D. (2008). Penelitian Tindakan Kelas. Jakarta: Bumi Aksara.

Curtis J. Bonk, Charles R. Graham, Jay Cross, M. G. M. (2009). The Hand Book of Blended Learning. Curtis J.(4).

Discoll, M. (2002). Blended Learning:Let's Get Beyond the Hype. IBM Global Services

Hartanto, W. (2016). Penggunaan E-Learning sebagai Media Pembelajaran. Jurnal Pendidikan Ekonomi: Jurnal Ilmiah Ilmu Pendidikan, Ilmu Ekonomi Dan Ilmu Sosial, 10(1).

Herbimo, W. (2020). Penerapan Aplikasi Moodle Sebagai Salah Satu Model Pembelajaran Jarak Jauh di Masa Pandemi. Ideguru: Jurnal Karya Ilmiah Guru, 5 (1 (Edisi Khusus KBM Pandemi COVID-19)), 107-113.

Husamah, H. (2014). Pembelajaran Bauran (Blended Learning). Jakarta: Prestasi Pustaka Raya.

Kaplan Pathway International. (2021). What is blended learning? https://www.kaplanpathways.com/ study-with-confidence/uk-blended-learning/

Mardapi, D. (2012). Pengukuran Penilaian \& Evaluasi Pendidikan. Yogyakarta: Nuha Medika.

Mardian, W., \& Sylvia, I. (2020). Upaya Meningkatkan Keaktifan Belajar Melalui Penerapan Model Students Divisions Achievement Divisions di XI IPS 1 SMANegeri 1 Bukittinggi. Jurnal Sikola: Jurnal Kajian Pendidikan dan Pembelajaran, 1(3), 207-214. https://doi.org/10.24036/ sikola.v1i3.31

Keputusan Menteri Pendidikan dan Kebudayaan Republik Indonesia Tentang Pedoman Pelaksanaan Kurikulum Pada Satuan Pendidikan Dalam Kondisi Khusus., Pub. L. No. 719/P/2020 (2020). Hamalik, O. (2001). Proses Belajar Mengajar. Jakarta: Bumi Aksara

Sudjana, N. (2006). Penilaian Hasil Proses Belajar Mengajar. Bandung: Remaja Rosdakarya.

Thorne, K. (2013). Blended Learning : How to Integrate Online and Tradicional Learning. London: Kogan Page Publishers.

Tri Mughni Indriani, Toto Fathoni, C. R. (2018). Implementasi Blended Learning dalam Program Pendidikan Jarak Jauh Pada Jenjang Pendidikan Menengah Kejuruan. Edutcehnologia, 2(2).

Widoyoko, E. P. (2009). Evaluasi Program Pembelajaran. Yogyakarta: Pustaka Pelajar. 